\title{
Demokratisk underskudd i helsetjenesten
}

\author{
Saken om hvorvidt det skal opprettes et nytt PCl-senter i Nordland illustrerer hvordan helsepolitiske beslut- \\ ninger er flyttet fra de folkevalgte til styrebordene. Politikerne er blitt lobbyister.
}

Ordførere fra 17 kommuner i Nordland står «samlet i kampen for én felles hjertesak». De mener at Helse Nord må si ja til å etablere et PCI-senter i Bodø (1).

Det regionale helseforetaket Helse Nord skal behandle saken i styremøte i slutten av februar. Utredningen Hjerteinfarkt og PCI $i$ Helse Nord ble sendt på høring i forkant (2). Et stort antall høringssvar fra kommuner, regionråd, Nordland legeforening, helsepersonell, Landsforeningen for hjerte- og lungesyke og andre vitner om høyt engasjement.

Hittil har befolkningen i Nord-Norge hatt mulighet for PCI-behandling ved hjerteinfarkt kun ved Universitetssykehuset Nord-Norge i Tromsø. Nå reises det krav om å kunne gi slik behandling også ved Nordlandssykehuset i Bodø. For pasientene i Nordland kan raskere tilgang til behandling ha stor helsemessig betydning. Fagmiljøet i Tromsø er imidlertid bekymret for lavere antall pasienter der.

Saken har betydelige helsepolitiske og helseøkonomiske dimensjoner. Utover de mange høringssvarene og innlegg på avisenes debattsider organiserer Landsforeningen for hjerte- og lungesyke fakkeltog gjennom
Bodøs gater til biblioteket. Der inviterer Nordlandssykehuset til foredraget Hvordan tenker spesialistene i Nordlandssykehuset at dette tilbudet bør organiseres (3).

For få år siden ville en slik sak selvsagt blitt fremlagt for politisk beslutning. Slik er

\section{«Styret i det regionale helseforetaket er ikke folkevalgt»}

det ikke lenger. Politikken er på tilskuerplass.

Styret i det regionale helseforetaket er ikke folkevalgt. Nå står 17 av våre fremste folkevalgte i Nordland - ordførerne - som lobbyister i en av de viktigste helsepolitiske sakene i Nord-Norge på lang tid. Bedre kan ikke det demokratiske underskuddet i spesialisthelsetjenesten illustreres.

\section{Kai Brynjar Hagen}

kai.brynjar.hagen@bodo.kommune.no
Kai Brynjar Hagen (f. 1949) er fastlege i Bodø kommune og overlege ved Nordlandssykehuset.

Forfatter har fylt ut ICMJE-skjemaet og oppgir ingen interessekonflikter.

\section{Litteratur}

1. Gulliksen S. Et samlet ordførerkorps til hjertekamp. En av dem var selv døden nær. Avisa Nordland 13.1.2017. www.an.no/helsevesen/helsenord/bodo/et-samlet-ordforerkorps-tilhjertekamp-en-av-dem-var-selv-doden-nar/s/ 5-4-457004 (17.1.2017)

2. Tollåli G. Høring: Hjerteinfarkt og PCl i Helse Nord. 11.11.2016. https://helse-nord.no/nyheter/ horinger/horing-hjerteinfarkt-og-pci-i-helse-nord (17.1.2017)

3. Gulliksen S. Fakkeltog og folkemøte om hjertesenter i Bodø. Avisa Nordland 13.1.2017. https://www.an.no/helsevesen/helse-nord/ nordlandssykehuset/fakkeltog-og-folkemote-omhjertesenter-i-bodo/s/5-4-457388 (27.1.2017).

Mottatt 17.1.2017og godkjent 27.1.2017. Redaktør: Ketil Slagstad.

Publisert først på nett. 